\title{
Coastal parents Perceptions of the Implementation of Early Childhood Education in Buton Islands
}

\author{
La Jeti $^{\circledR}{ }^{\bowtie}$, Manan $^{2}$ \\ Pendidikan Anak Usia Dini, Universitas Muhammadiyah Buton, Indonesia(1) \\ Pendidikan Sekolah Dasar, Universitas Muhammadiyah Buton, Indonesia(2) \\ DOI: $\underline{10.31004 / o b s e s i . v 6 i 4.2240}$
}

\begin{abstract}
The purpose of this study was to obtain information on understanding of early childhood education in coastal communities in the Buton Islands. This research uses descriptive qualitative research. The subjects in this study were teachers, and parents in the coastal district of Buton. Based on the results of the study, the coastal communities in the Buton Islands do not yet fully have knowledge about the nature of early childhood development. Based on the results of the study showed that parents could not distinguish between ECE and Kindergarten. Kindergarten in not part of ECE and so that in learning process, parents emphasis on academic achievement without providing the the character building. Parents only focus on on reading and writing without paying attention to aspects of moral and religious values, physical, motor, social, emotional. In the aspect of the role of involvement, it shows the lack of role as parents of students to be involved in the implementation of early childhood education including parenting program activities, volunteers, communication, collaboration and learning at home. Lack of understanding of coastal parents in Buton Islands towards the implementation of early childhood education, it is necessary for schools to involve families in educational programs in order to gain enlightenment and knowledge about early childhood education.
\end{abstract}

Keywords: costal; community; perceptions

\begin{abstract}
Abstrak
Tujuan dari penelitian ini adalah untuk memperoleh informasi tentang pemahaman pendidikan anak usia dini pada masyarakat pesisir di Kepulauan Buton. Menggunakan penelitian kualitatif deskriptif dengan subjek guru, dan orang tua di wilayah pesisir Kabupaten Buton. Hasil penelitian menunjukkan, masyarakat pesisir di Kepulauan Buton belum sepenuhnya memiliki pengetahuan tentang hakikat perkembangan anak usia dini. Orang tua tidak dapat membedakan PAUD dan Taman Kanak- Kanak. Taman Kanak-kanak bukan bagian dari PAUD sehingga dalam proses pembelajaran, orang tua menekankan pada prestasi akademik tanpa memberikan pembinaan karakter. Orang tua hanya fokus membaca dan menulis tanpa memperhatikan aspek lainnya. Pada aspek peran keterlibatan menunjukkan kurangnya peran sebagai orang tua siswa untuk terlibat dalam pelaksanaan PAUD meliputi kegiatan program parenting, volunteer, komunikasi, kolaborasi dan belajar di rumah. Diperlukan peran sekolah untuk melibatkan keluarga dalam program pendidikan agar mendapatkan pencerahan dan pengetahuan tentang pendidikan anak usia dini.
\end{abstract}

Kata Kunci: pesisir; komunitas; persepsi

Copyright (c) 2022 La Jeti, Manan

$\triangle$ Corresponding author :

Email Address : lajeti469@gmail.com (Buton, Indonesia)

Received 4 September 2021, Accepted 23 January 2022, Published 26 January 2022

Jurnal Obsesi : Jurnal Pendidikan Anak Usia Dini, 6(4), 2022 | 2656 


\section{INTRODUCTION}

Indonesia is an archipelagic country which stretches from Sabang to Merauke. Indonesia is also called a maritime country where almost every island is a coastal land, especially in eastern Indonesia. The geographical location of an area will greatly determine the pattern of education because it is influenced by the characteristics of society, social culture and access to education. The current state of education in Indonesia cannot be said to be evenly distributed. This causes difficulty in accessing education in remote and coastal areas, thus requiring serious efforts to equalize education. Education is the right of the nation's children without having to differentiate between ethnicity, race and religion so that efforts to educate the nation's children are the ideals of independence. Eastern Indonesia is a coastal area that is difficult to access so that education is not as optimal as access to urban education. Slow access to education is the main factor hindering the education process in coastal areas. This case supported the research conducted by (Sakti, 2021)showed that problem faced the students, teacher and parents in learning process namely, skill in operating learning technology, internet accsess no supported, lack of references. This research giving the information to government, teacher and parents how to make the study tobe better spesialy in pandemic situation.

Education is a process of changing human behavior from bad to good, from not knowing to knowing. According to (Santrock, 2021) ducation is the process to change the behavior through the experience in environment. The description illustrates that the environment plays an important role in providing education. Families, schools and communities are elements of education with good commitment and cooperation so that education can be realized as the ideals of independence are to educate the nation's life. According to (Hendratmoko et al., 2018) hat education is an effort to form a child's noble character and a balance between intention, taste and creativity. For him, the family plays an important role in realizing education from an early age, starting from infancy to adulthood. Ki Hadjar Dewantara's educational concepts regarding PAUD become a reference for the implementation and development of PAUD in Indonesia from urban centers to rural and coastal communities. Early childhood education is a process of providing guidance, care, education and mentoring services to stimulate children's potential optimally. Early childhood education aims to develop children's potential, both in basic abilities and in shaping their personality.

Early childhood is a child aged 0 to 6 years. This age is very potential so it requires optimal stimulation from the environment. This potential includes brain development and physical motor growth, namely at the age of children 0 to 8 years their brain development is very rapid up to $80 \%$. The potential absorption of children's brains makes children different from children who are more than 8 years old or elementary school children. Children with the potential to reach $80 \%$ of this for Maria Montesori call it the absorbent mind. He believes that children have absorbent brains, this child's brain has the ability to absorb various information in their environment. (Santrock, 2021) children with this potential classify it in the sensorymotor stage and the pre-operational stage. Where children at the motor sensor stage are able to absorb various information through their senses. While (Rachmi et al., 2016a) early childhood has unique learning patterns such as: Children learn through relationships with responsive adults, meaning that children through communication with their environment, adults around them can construct their knowledge. Active hands On Involvement. Early childhood is essentially to develop their abilities by involving their senses and being active. In addition, children also develop their abilities through direct experience or what is called Meaningful experience and Constructing understading of the world. This shows that the environment, both school and community, needs to provide space and encouragement for children. In addition, improving the quality of education for the Santa family is important.

Current conditions, the implementation of early childhood education has experienced a massive increase. Not only in urban areas to remote rural areas. This shows that the importance of early childhood education is so important. The government through various 
policies and regulations regarding Early Childhood Education, namely the implementation of Integrative Holistic-based early childhood education. This integrative Holistic PAUD service requires the cooperation of various parties or stakeholders, including families, communities and the government.

According research conducted by (Lakes et al., 2019) showed that patenership in early childhood education program namely parents, teacher, caregivers could give impack to understanding child development. Parents understood giving the appropriate education, minimize the risk to child growing and development.

The problem currently being faced in the field is the interest of the family in enrolling their child in Kindergarten. Society in general still thinks that early childhood education is not important so that children do not need to enter ECE. For parents, the most important thing is that their children enter elementary school because elementary school is considered a formal school. This is due to the lack of public awareness about early childhood education, so that efforts are needed to provide an understanding to the public about the basic concepts of early childhood education. Based on observations of coastal communities, in general, people have a livelihood at sea (fishing), parents' busy activities to earn a fortune sometimes neglect their children's schooling, with this habit children from kindergarten age spend more time fishing together. his family. From the results of this observation, there are also parents who send their children to kindergarten, but only to enter their children to stay in school. Researchers seeing this condition realize that in general parents do not realize that education is very important and is part of the responsibility. Parents are reluctant to be asked for cooperation as education partners. Parents realize that education is the full responsibility of teachers and schools, so the education process in coastal communities has not been going well. Meanwhile, the results of interviews in the field showed that there were parents who did not understand the purpose of early childhood education. Based on the research conducted by (Redouane et al., 2016)showed that Parents perception could give the understading how child learning by the technologies at home and could compared healthy children and other disease cohorts.

This needs to be enlightened to the community about the purpose of providing early childhood education and the importance of parental involvement as educational partners. According to (Morrison, 2012) the involvement of parents in the provision of early childhood education is very important to realize an effective education.

People's perceptions of early childhood education are found in various fields, including the existence of people's thoughts that early childhood education is education that can be carried out by parents themselves in the family environment, there are those who think that early childhood education is not important to follow. by children, so the main alternative is to enroll children in elementary school because it is considered elementary school as a formal school and must be followed.

Based on research conducted by (Cheng et al., 2016) showed that parent did not understand of child development could not give the good stimulation at home namely how giving the food, parenting, learning at home and make warm comucation. So that parents and caregivers should to educate about the early childhood education. The community's perception must continue to be developed through outreach activities for parenting programs, and early childhood education seminars. On other hand, it supported by the research conducted by (Meloni et al., 2015)showed that The present research verified whether children's disability representations are influenced by cultural variables (social activities, parent education, and custom complex variables) or by cognitive constraints. At an early age, children have a disability representation characterized by a vision of the person with disability mainly as sick and whose diversity is strictly connected to health. Based on these initial problems, researcher formulate the problem research was How is Coastal Community Perceptions of the Implementation of Early Childhood Education in Buton Islands. 


\section{METHODS}

This type of research is descriptive qualitative research, where the data collected is in the form of words, pictures, not numbers. Qualitative research is a research procedure that produces descriptive data in the form of written or spoken words from people and observed behavior. Descriptive research is a form of research aimed at describing or describing existing phenomena. The purpose of descriptive research is to make a systematic, factual, and accurate analysis of the facts and characteristics of a particular population or area. This study was used to determine how is Coastal Community Perceptions of the Implementation of Early Childhood Education in Buton Islands.

The subjects in this study were 2 coastal teachers, 15 families in Buton island. The teacher's criteria are Kindergarten Teachers. The criteria for parents are parents for those who have children in Kindergarten. The data collection of this research used the technique The purposive sampling technique was chosen because the source of information is a source and is rich in information about the phenomenon to be studied. Data Collection Techniques In terms of collecting this data, the authors go directly to the object of research to get valid data, the researchers used observation to obtain the data about the program that organized by schools and parents and interview in using to obtain the data of the teachers and parents involevement in childhood education.

Analysis of the data used is descriptive analytical method, which describes the data collected in the form of words, pictures, and not numbers. Data that comes from scripts, interviews, field notes, then described so that it can provide clarity on reality or reality. Data analysis in qualitative research is carried out before entering the field, while in the field and after finishing in the field. According to Miles and Huberman's version of data analysis, there are three flow of activities, namely data reduction, data presentation, and drawing conclusions or verification (Picture 1)

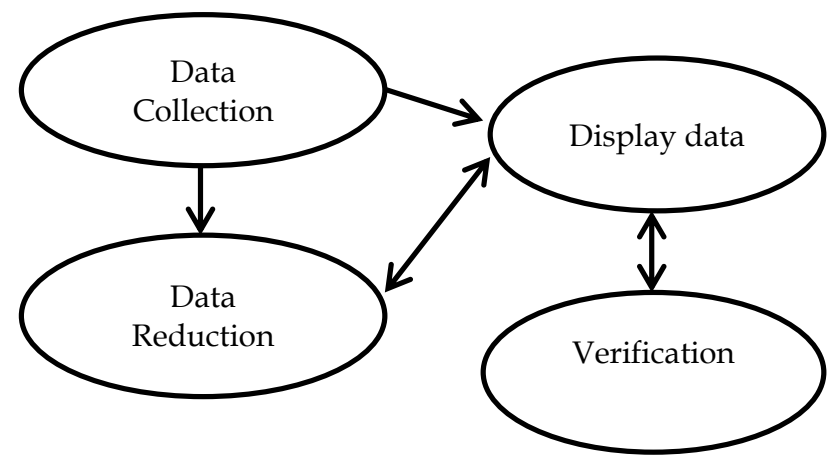

Picture 1. Chart Miles and huberman qualitative data analysis

\section{RESULT AND DISCUSSION}

Organizing early childhood education is the ideals of Indonesian independence as an effort to educate the nation's generation from an early age. Early childhood education as contained in Law No. 20 of 2003 concerning the national education system has had the direction of developing early childhood education, namely realizing Indonesian children of hope with comprehensive intelligent people in 2045. In an effort to realize quality early childhood education requires competent human resources for education. In this case, the Buton Islands community take an important role in the effort to realize competitive early childhood education.

Buton archipelago is an area consisting of several islands where the majority of the people live on the coast. Communities on the coast of Buton Islands generally work as fishermen, both father and mother, so the education of their children is less of a concern. Meanwhile, according to (Bronfenbrenner, 1979) the microsystem environment is important to be carried out optimally because of the cooperative relationship between education 
providers, namely families and schools. This is a serious problem for coastal communities in the Buton Islands. Family understanding of early childhood education is the main key to the implementation of maximum early childhood education. Understanding can bring family awareness to involve themselves in optimally organizing early childhood education. In the implementation of optimal early childhood education, families must have standard knowledge of early childhood education including: The nature of early childhood education, the purpose of providing early childhood education in the form of involvement in education, the role of parents in the family environment as a form of involvement, parents understand the stages of child development, the development of character education in the current global area. Parents' knowledge about the importance of early childhood education can support a holistic, integrative education program. Parents who have knowledge of the nature of early childhood education can understand the basic concepts of early childhood education, namely early childhood education as an effort to provide stimulation to aspects of child development which include: development of moral and religious values, physical motor, social emotional development, language development, cognitive development and aspects of artistic development. In addition, parents have an understanding of how to be involved in the provision of education, of course, through programs of parenting, volunteers, communication, collaboration and carrying out learning at home as a form of developing students in the family environment.

According the research conducted by (Harf et al., 2013)indicated that from the parents' perspective and explores their experiences of these first meetings. Parents learn how make postitive parenting, how involved to school, parents could prepared their chils before join to school. This research giving the invormation to parents and teachers that collaboratios is very important as the pathnership in education.

The purpose of early childhood education must also be understood by parents so that the presence of this educational institution is warmly welcomed by the community, especially those with early childhood. Sufficient knowledge is able to provide awareness that the presence of early childhood education is a good thing for coastal children. Because through early childhood education, coastal children generally do not know letters, numbers, lack character and other aspects of development are not optimal.

While the research conducted by (Cheng et al., 2016) showed that The educational attainment of each parent was negatively associated with child disability in China. The education of mothers played a more critical role than that of fathers in child disability. It indicated that parents with their understanding in child education could give the role important in guidance, teaching, and collaboration with the teachers.

Based on the results of research on the understanding of parents in coastal communities about early childhood education, it shows that parents do not fully understand the basic concepts and goals of early childhood education so that the presence of children's educational institutions is considered normal by the community.

\section{Understanding of ECE}

An understanding of early childhood education is very important for the realization of competitive early childhood education. This understanding of early childhood education certainly includes: the nature of early childhood, the goals of early childhood education, the characteristics of child development and stimulation. Coastal communities in Buton Islands understand ECE only as a school like children aged 4-6 years whose learning content is reading and writing so that it ignores other aspects of development such as moral and religious values, physical, motor, social, emotional, language and art.

According research conducted by (McConnell et al., 2020) concluded that teacher and parents should make good collaboration in parepared child education. Parents active involve in school program supports child studing and support by learimg at home. This research 
indicated that collabotaion is important to give information to parents how is child learning in kindergarten.

Based on the results of the study showed that parents could not distinguish between ECE and Kindergarten. Kindergarten in not part of ECE and so that in learning process, parents emphasis on academic achievement without providing the the character building. Parents' perception in Early childhood Education could be showed at Picture 2.

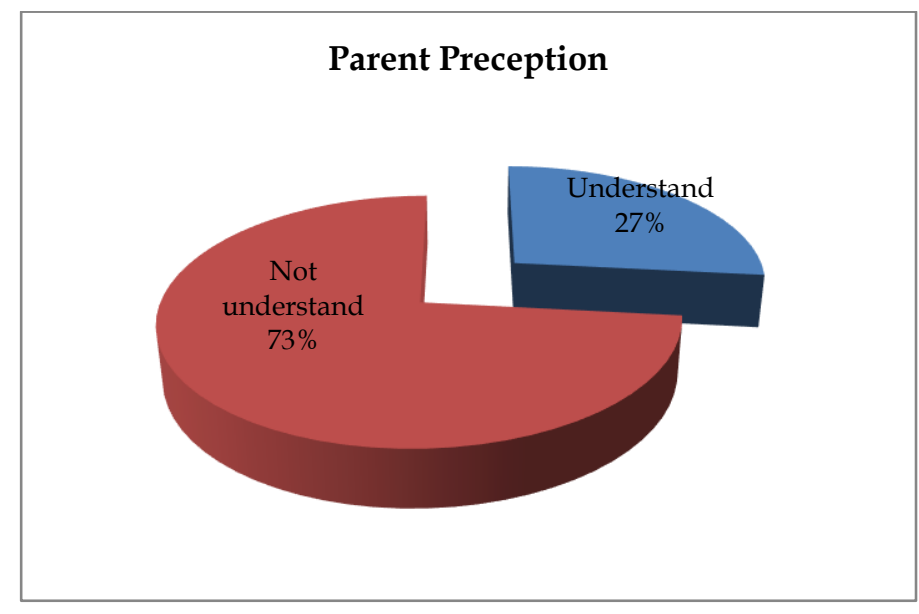

Picture 2. Chart of parents' preception

Based on the chart parents only 4 parents or $27 \%$ parents understand about ECE and 10 or $73 \%$ parents do not understand the nature of early childhood development that early childhood is a very potential and critical age. Because of its potential, it is called the golden age, at this age parents must understand that children have unique developmental characteristics, are adventurous, energetic, active, imaginative, young and angry so parents must provide stimulation patterns according to their age and stages of development.

Research conducted by (Irma et al., 2019)The results showed that parents collaboration with schools, namely: parenting education, information about education, development, and children's health, home learning, child performance performances, recreation, collaboration with community communities (top theme), home visits by teacher, and participation in school activities. So that parents could understand how is early childhood education and what importan child learning.

Coastal parents in the Buton Islands do not fully understand the goals of early childhood education. Based on the results of research on the purpose of ECE, it shows that parents' understanding of the purpose of ECE is only as a place for children to learn to write and count. This shows that parents in the coastal community of Buton only focus on children's education on language and cognitive aspects without paying attention to aspects of moral and religious values, physical, motor, social, emotional, and art.

\section{Understanding the Role of Parents in ECE}

Parental involvement is the most important aspect in early childhood education, because parents have the most active role in the child's growth and development. So there is a need for an edu parenting program carried out by schools to provide insight into knowledge about early childhood education. According to Henderson et al (in Ferara \& Ferara, 2005) that parental involvement is very important to support children's learning, both in formal schools and in learning courses. Parental involvement as parental participation in the process and experience of children's education. This shows that the existence and role of parents is considered very important in the child's education process. Based on the results of research on the coastal community of Buton Islands regarding the role of involvement in the implementation of ECE, it shows the lack of a role as parents of students to be involved in the 
implementation of early childhood education including parenting program activities, volunteers, communication, collaboration and learning at home. Parents' Understanding the Role of Parents in ECE could be showed at the chart at Picture 3.

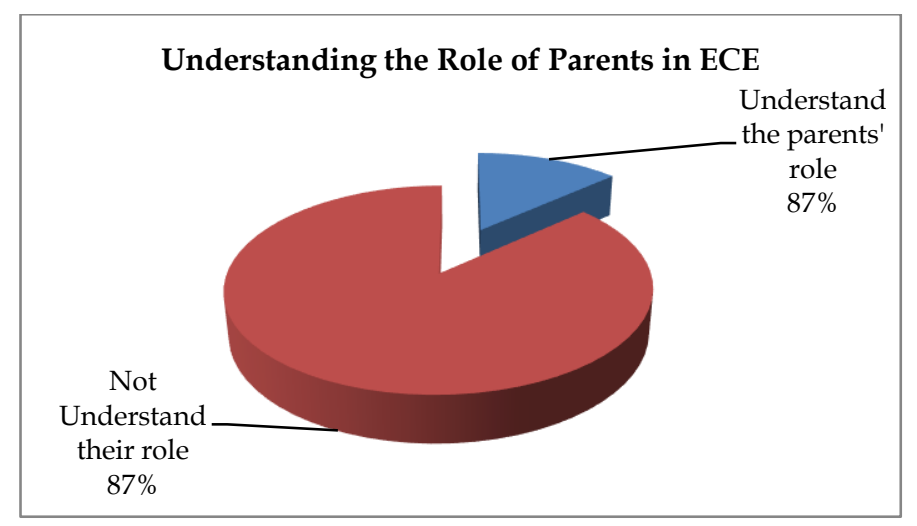

Picture 3. Chart of Parents' Understanding the Role of Parents in ECE

Based on the result of this research parents only $13 \%$ understand their role in early childhood education. The understanding of parents in the coastal community of Buton that the education and development of children is completely left by the school, the parents of students are only present when taking reports on children's development. According research conducted by (Karthik et al., 2014) concluded that parents with good perception in early childhood education, they could giving good stimulation in learing at home, because parents understand the schools program.

This shows that the involvement of parents in the implementation of early childhood education in coastal communities does not play a good role so that parents do not understand their role in the program of early childhood education activities. Parents of students need to be involved in various school activities so that they can create a home environment that supports children as students and obtains information about health, safety, nutrition and everything related to child development. Parents of coastal communities in the Butun Islands need information about their role as educational partners so that they can help facilitate the task of child development. In addition, schools and families can build communication to more easily obtain information about children's growth and development and school programs. Based on the research conducted by Luluk Asnawati(Handayani, 2021)

Parents play an important role as mentors, educators, and supervisors in responding to the use of gadgets by children. This is done so that children do not abuse gadgets for other activities. Parents can accompany children when operating gadgets as a form of parental care for their children. The results of this study can be used as a guide for parents in utilizing technology so that parents can maximize their role with all the developments that occur Good communication is certainly needed by parents as the main figures in communicating the progress of education by schools, as well as the school can be a companion to be able to provide good information to parents as partners in encouraging and motivating for the continuity of early childhood education. While research conducted by (Almeida et al., 2021) showed that parents with understanding child education has the role important in care and teaching the children. Parents have the knowledge of child development, so that could teach their child at home according to development appropriate practice and could make effective collaboration.

The results of this study indicate the lack of parental roles in assisting children's learning at home. Learning assignments obtained at school are not carried out by family learning assistance at home. According research conducted by (Bertille et al., 2013)Our study suggests that concordance of parents' knowledge and practices with recommendations for managing in their children has improved since the last studies on the subject, varied widely by studied key management steps, and was related to some parent and characteristics. 
This shows that the awareness of parents in coastal communities about ECE is very low, so there is a need for fostering efforts carried out by ECE to provide new knowledge and be fully involved in the implementation of education. Parental assistance in learning at home in question is parental activities in helping children learn at home based on activities at school, such as helping children do homework, reading story books that educate children. Parents act as companions and facilitators of children in teaching and guiding to complete learning that is considered difficult. Based on the research conducted by (Rachmi et al., 2016b)indicated that parent interventions to support affected children and their families in particular after the end of treatment, e.g. a multidisciplinary approach with several modules which can be tailored according to individual needs. Oktarina Dwi Handayani (Handayani, 2021)Based on the research findings, it was found that parents of children aged 5-6 years at PAUD institutions in the city of Bekasi had a positive perception of the implementation of BDR. The results of this study illustrate that the implementation of BDR can be carried out effectively through the support of facilities and infrastructure from educational institutions and parents of students. Based on the perception of parents, the implementation of BDR can run well through learning planning, teaching materials and materials as well as assessment carried out at BDR.

The role of parents in education as a form of responsibility is considered to be contributing to the sustainability of activities at school. Empathy and full of responsibility become a benchmark for the next learning decision. Lack of understanding of coastal parents on the implementation of early childhood education, it is necessary for schools to involve families in educational programs in order to get enlightenment and knowledge about early childhood education.

\section{CONCLUSION}

This research could be concluded that basically the people on the coast of Buton Islands do not fully have knowledge about the implementation of early childhood education. Parents who have students only know that early childhood education is education before entering elementary school and does not require parents to enroll their children in Kindergarten. On other hand Parents' lack of understanding of their role in early childhood education participation in learning programs, establishing good communication, collaboration and home learning assistance. It is the main task for teachers to involve the parents to improve the quality in schools program early education.

\section{ACKNOWLEDGMENT}

Alhamdulillahi rabil 'alamin, the researcher expresses the highest gratitude to Allah Subhanahu wa ta'alaa, for blessing, love, apportunity, health and mercy to complete this paper. Appreciation and thanks to Dr. Wa Ode Alzarliani, S.P.,M.M. as the Rector of Muhammadiyah Buton University who have given the support and motivation. Appreciation and thanks to informan who have given the information for completing this research. Appreciation and thanks to Obsesi Journal as Publisher this paper.

\section{REFERENCES}

Almeida, C., Azevedo, J., Gregório, M. J., Barros, R., Severo, M., \& Padrão, P. (2021). Parental practices, preferences, skills and attitudes on food consumption of pre-school children: Results from Nutriscience Project. PloS One, 16(5), e0251620. https://doi.org/10.1371/journal.pone.0251620

Bertille, N., Fournier-Charrière, E., Pons, G., \& Chalumeau, M. (2013). Managing fever in children: A national survey of parents' knowledge and practices in France. PloS One, 8(12), e83469. https:/ / doi.org/10.1371/journal.pone.0083469

Bronfenbrenner, U. (1979). The ecology of human development. Harvard university press. 
Cheng, T. S., Loy, S. L., Cheung, Y. B., Chan, J. K. Y., Tint, M. T., Godfrey, K. M., Gluckman, P. D., Kwek, K., Saw, S. M., \& Chong, Y.-S. (2016). Singaporean mothers' perception of their three-year-old child's weight status: A cross-sectional study. PloS One, 11(1), e0147563. https:// doi.org/10.1371/journal.pone.0147563

Copple, C., \& Bredekamp, S. (2009). Developmentally appropriate practice in early childhood programs serving children from birth through age 8. ERIC.

Handayani, O. D. (2021). Persepsi Orangtua terhadap Pelaksanaan Belajar dari Rumah pada Pendidikan Anak Usia Dini. Jurnal Obsesi: Jurnal Pendidikan Anak Usia Dini, 5(2), 1754-1763. https:// doi.org/10.31004/obsesi.v5i2.975

Harf, A., Skandrani, S., Radjack, R., Sibeoni, J., Moro, M. R., \& Revah-Levy, A. (2013). First parent-child meetings in international adoptions: A qualitative study. PLoS One, 8(9), e75300. https://doi.org/10.1371/journal.pone.0075300

Hendratmoko, T., Kuswandi, D., \& Setyosari, P. (2018). Tujuan Pembelajaran Berlandaskan Konsep Pendidikan Jiwa Merdeka Ki Hajar Dewantara. JINOTEP (Jurnal Inovasi Dan Teknologi Pembelajaran): Kajian Dan Riset Dalam Teknologi Pembelajaran, 3(2), $152-$ 157.

Irma, C. N., Nisa, K., \& Sururiyah, S. K. (2019). Keterlibatan orang tua dalam pendidikan anak usia dini di TK Masyithoh 1 Purworejo. Jurnal Obsesi: Jurnal Pendidikan Anak Usia Dini, 3(1), 214-224. https:// doi.org/10.31004/obsesi.v3i1.152

Karthik, L., Kumar, G., Keswani, T., Bhattacharyya, A., Chandar, S. S., \& Bhaskara Rao, K. (2014). Protease inhibitors from marine actinobacteria as a potential source for antimalarial compound. PloS One, 9(3), e90972. https://doi.org/10.1371/journal.pone.0090972

Lakes, K. D., Vaughan, J., Radom-Aizik, S., Taylor Lucas, C., Stehli, A., \& Cooper, D. (2019). Development of the Parent Perceptions of Physical Activity Scale (PPPAS): Results from two studies with parents of infants and toddlers. PloS One, 14(5), e0213570. https:// doi.org/10.1371/journal.pone.0213570

McConnell, E. L., Black, S. A., McClelland, J. F., McKerr, L., Dillenburger, K., Anketell, P., Jackson, A. J., Little, J.-A., \& Saunders, K. J. (2020). Parents and teachers of children in special education settings value in-school eyecare and written reports of visual status. PloS One, 15(9), e0238779. https:// doi.org/10.1371/journal.pone.0238779

Meloni, F., Federici, S., \& Dennis, J. L. (2015). Parents' education shapes, but does not originate, the disability representations of their children. PLoS One, 10(6), e0128876. https:// doi.org/10.1371/journal.pone.0128876

Morrison, G. S. (2012). Dasar-dasar pendidikan anak usia dini (PAUD). Jakarta: Indeks.

Rachmi, C. N., Agho, K. E., Li, M., \& Baur, L. A. (2016a). Stunting, underweight and overweight in children aged 2.0-4.9 years in Indonesia: Prevalence trends and associated risk factors. PloS One, 11(5), e0154756. https:// doi.org/10.1371/journal.pone.0154756

Rachmi, C. N., Agho, K. E., Li, M., \& Baur, L. A. (2016b). Stunting, underweight and overweight in children aged 2.0-4.9 years in Indonesia: Prevalence trends and associated risk factors. PloS One, 11(5), e0154756. https:// doi.org/10.1371/journal.pone.0154756

Redouane, B., Cohen, E., Stephens, D., Keilty, K., Mouzaki, M., Narayanan, U., Moraes, T., \& Amin, R. (2016). Parental perceptions of quality of life in children on long-term ventilation at home as compared to enterostomy tubes. Plos One, 11(2), e0149999. https:// doi.org/10.1371/journal.pone.0149999

Sakti, S. A. (2021). Persepsi Orang Tua Siswa terhadap Pembelajaran Daring pada Masa Pandemi Covid 19 di Yogyakarta. Jurnal Obsesi: Jurnal Pendidikan Anak Usia Dini, 6(1), 73-81. https://doi.org/10.31004/obsesi.v6i1.804

Santrock, J. W. (2021). Psikologi pendidikan. 